\section{Morgagni and the impact factor}

SIR - The recent debate about the impact factor (IF) and citation index as a measure of scientific value, especially in competition for university posts in Italy, is a reminder that this is nothing new. The University of Padua's medical faculty recently introduced an 'impact factor' threshold for future members of its scientific and development commissions ${ }^{1}$. This procedure has a long but forgotten tradition.

Throughout his long and prolific career, Giovanni Battista Morgagni (1681-1771), probably the most renowned anatomist and pathologist of the eighteenth century, and a professor at Padua from 1712 to his death, collected in a register all citations of his work. This was only one aspect of Morgagni's self-promotion, which was also aimed at attracting the attention of other scholars so that they would disseminate information about him.

During his lifetime, Morgagni was honoured with a monument commissioned by the Natio Germanica students who attended Padua's Studio. During the nineteenth century, a century of great change in the field of medicine, Morgagni's supremacy in introducing the 'anatomic idea' into pathology was not forgotten, as Rudolph Virchow demonstrated $^{2}$. Even today, Morgagni is the subject of a plentiful literature and is often cited in databanks. To test the contemporary 'impact' of Morgagni's work would be difficult; fortunately, Morgagni himself has done a good part of this work, registering for more than 60 years (from 1704 to 1768 ) all the citations of his name ${ }^{3}$. Morgagni was perfectly aware of the importance of controlling the circulation of his work and its acceptance by colleagues. It is noteworthy that much of his collection of private letters - often intended from the first for publication - was concerned to promote his image as a man, physician and scientist. Moreover, an important part of his work Adversaria Anatomica was devoted to refuting the criticisms of his detractors.

Morgagni did not limit himself to collecting citations about himself, but also promoted them by keeping his colleagues informed about the progress of his research. As soon as accounts of his work were published, he selectively distributed them among a few authorities and then made their favourable assessments known. His autobiographies are rich in detailed references to the citations ${ }^{4}$.

How much did Morgagni's self-promotion contribute to his fame among his contemporaries? A comparison could be made with his friend and colleague, Antonio Vallisneri (1661-1730), a professor at Padua from 1700 to his death. Vallisneri was no less active in his own field of natural history than the anatomist ${ }^{5}$, yet much of Vallisneri's innovative research was ignored by his contemporaries and by most historians of biological thought.

Citation analysis does not always indicate the quality and impact of an individual's work. The best ratio between production and promotion in science is perhaps the critical point of the scientific quality valuation. Using citation analysis and IF tout court as a mechanical replacement for careful human judgement cannot change a John Doe into Morgagni.

Maurizio Rippa Bonati

Istituto di Storia della

Medicina, Universita,

via G. Falloppio 50 ,

I-35121 Padova, Italy

Andrea G. Drusini

Department of Biology,

University of Padova,

Via Trieste 75 ,

I-35121 Padova, Italy

1. Calzà, L. \& Garbisa S. Nature 374, 492 (1995).

2. Virchow, R. Morgagni und der anatomische Gedanke Verlag von August Hirschwald, Berlin, 1894).

3. Morgagni, G. B. Catalogo cronologico (1704-1768) delle opere a stampa nelle quali sono citati gli scritti di G.B. Morgagni, o si parla di lui e del suo merito scientifico, Vol. 16. Ms. cc. 95 (Biblioteca Comunale di Forli, Fondo G. B. Morgagni).

4. Morgagni, G. B. in Opera Postuma. Ms. Laurenziano Fondo Ashburnhamiano (ed., Pazzini, A.) Vol. I, 227-159, (Istituto di Storia della Medicina dell'Università, Roma, 1964).

5. Omodeo, P. Antonio Vallisneri fra Padova e l'Europa scientifica del primo settecento, ANMS 9(1), 3-4 (1982).

\section{Not revisionist}

SIR - In his review (Nature 380, 399-400; 1996), Paul Weindling calls my recent book Biologists under Hitler a "revisionist verdict" that denies the impact of the Jewish emigration on modern biology in post-war Germany. Indeed, I stated that, despite serious losses, "emigration alone is not a sufficient explanation for the lag in biology in Germany after World War II". But I attributed this lag to the emigration and to the moral failure of virtually all German non-Jewish biologists. I said that they violated the scientific principle of universalism by accepting the expulsion of their Jewish colleagues almost unopposedly, collaborated loyally with the Nazi government, and thus broke off dialogue with their international colleagues. As a consequence, German biologists - with the exception of a very few individual scientists - did not participate in international scientific exchange for several years after 1945. I pointed out that this self-inflicted isolation of German biologists contributed decisively - in addition to the forced emigration to the late onset of molecular biology in post-war Germany. Should this reasoning be called a revisionist verdict?

\section{Ute Deichmann}

Institut für Genetik,

Universität zu Köln,

Weyertal 121, D-50931 Köln, Germany
Women scientists

SIR - I read June Goodfield's review (Nature 380, 306-307; 1996) of Margaret W. Rossiter's new book, Women Scientists in America: Before Affirmative Action 1940-1972, with great interest, and I plan to buy the book when I go "back to where I came from". Where I came from most recently is the Massachusetts Institute of Technology (MIT). At MIT there are four women faculty in a biology department of 60 faculty, and one of those women asked me once, "Where are the women?" I don't know, but I know that we are out of science before we reach faculty level. If we remain, we drift about from postdoc to postdoc, and, in my case, from country to country.

But the reason for this letter is to defend my own women's college, Smith. I loved MIT and the informal, creative intelligence of its biology professors, but nowhere has ever been as intellectually fulfilling for me as my women's college, and I certainly do not feel "betrayed". At Smith, I was surrounded by people who not only believed I could excel in mathematics, physics and biology, but who also expected it. Since I recently applied for a directorship of a programme on women and science, I have been thinking about why I am one of four women at my career stage in the Max-Planck-Institut für Molekulare Pflanzenphysiologie, and why we, as postdocs, are the most advanced women at this institute. In my case, the reason is in great part Smith College. Without the four years of being trained by Jill Ker Conway to believe very firmly in our abilities, I doubt whether I would even have a $\mathrm{PhD}$, much less have had postdoctoral fellowships at Harvard, MIT and the MaxPlanck and my own independent research project.

Goodfield refers to "...a cadre of highly qualified women who had no place to go except back to where they came from - the women's colleges". Exactly! Highly qualified women were and are coming from women's colleges. More than 75 per cent of the graduates from Smith College go on to graduate work. Without education in women's colleges, there wouldn't even have been a question of where women were going because there wouldn't have been any highly educated women. Where did the women's movement start to get any of us here in science in the first place? It certainly did not start at the Harvard Faculty Club. It was with Gloria Steinem, graduate of Smith College, founded by a woman named Sophia Smith who fought against the notion prevalent in her time that higher education was bad for women's health. Women's colleges put us in science and they will foster the women who come up with the ideas to keep us in science. Ellen V. Kearns

Max-Planck-Institut für

Molekulare Pflanzenphysiologie, Karl-Liebknecht-Str. 25, Haus 20 , 14476 Golm, Germany 